\title{
Pengembangan Teknik Cerdas Cermat Kimia Berbasis HOTS dalam Model Team Games Tournament untuk Meningkatkan Motivasi Belajar dan Keterampilan Berpikir Kritis Peserta Didik
}

\author{
Surya Ningsi \\ Pendidikan Kimia, Universitas Negeri Makassar \\ Email: uyaamaya2010@gmail.com \\ Tabrani Gani \\ Pendidikan Kimia, Universitas Negeri Makassar \\ Email: tabrani.gani@yahoo.com \\ Army Auliah \\ Pendidikan Kimia, Universitas Negeri Makassar \\ Email: auliaarmy@gmail.com
}

(Diterima: 10-Juli-2020; direvisi: 11-Agustus-2020; dipublikasikan: 15-September-2020)

\begin{abstract}
Abstrak: Penggunaan teknik yang tepat sangat menentukan keberhasilan pencapaian kompetensi peserta didik dalam pembelajaran. Teknik pembelajaran yang cenderung monoton membuat peserta didik kurang terlibat aktif dalam pembelajaran dan kurang melatih keterampilan berpikir kritis peserta didik. Pengembangan teknik cerdas cermat kimia berbasis HOTS dalam Model TGT diharapkan efektif diterapkan dalam kelas dan membantu peserta didik dalam pembelajaran kimia. Penelitian pengembangan ini bertujuan untuk mengetahui: 1) gambaran pengembangan teknik cerdas cermat kimia berbasis HOTS dalam Model TGT; dan 2) kualitas teknik cerdas cermat kimia berbasis HOTS dalam Model TGT untuk meningkatkan motivasi belajar dan keterampilan berpikir kritis peserta didik pada materi struktur Atom. Penelitian ini terdiri dari tahap analisis, perancangan, pengembangan, implementasi dan evaluasi. Produk yang dikembangkan diuji coba pada 35 peserta didik kelas X MIA 4 SMA Negeri 3 Bone Tahun Pelajaran 2019/2020. Kevalidan produk diuji oleh dua orang validator ahli. Penelitian ini meliputi langkah-langkah Model TGT, yaitu penyajian kelas, belajar kelompok, games, turnamen dan penghargaan. Tahapan cerdas cermat kimia ini dimulai pada kegiatan mengasosiasi dan disajikan dalam bentuk kuis atau pertanyaan yang menggunakan soal-soal HOTS disertai dengan games untuk memotivasi peserta didik dalam belajar dan berpikir kritis. Hasil penelitian menujukkan: 1) rata-rata nilai kevalidan produk adalah 3,71 (sangat valid); 2) data angket motivasi belajar $\overline{\mathrm{X}}=3,31$ (tinggi); 3) hasil rata-rata nilai N-Gain KBK adalah 0,79 (tinggi); 4) Guru dan peserta didik menunjukkan respon yang sangat positif dengan persentase $96,88 \%$ dan $87,11 \%$. Hal ini dapat disimpulkan bahwa teknik cerdas cermat kimia berbasis HOTS dalam Model TGT yang telah dikembangkan dalam pembelajaran kimia materi Struktur Atom valid, praktis dan efektif untuk meningkatkan motivasi belajar dan keterampilan berpikir kritis peserta didik.
\end{abstract}

Kata kunci: Teknik Cerdas Cermat Kimia; HOTS; TGT; Motivasi Belajar; Keterampilan Berpikir Kritis.

Abstract: The use of appropriate techniques will determine the success of achieving student competencies in learning. Learning techniques that tend to be monotonous make students less actively involved in learning and less training students' critical thinking skills. Development of chemistry quiz technique based on HOTS in TGT Model is expected to be implemented 
effectively in class and assist students in learning chemistry. This development research aims at discovering: (1) the description of the development of chemistry quiz technique based on HOTS in TGT Model; and (2) the extent of the quality of chemistry quiz technique based on HOTS in TGT Model to enhance learning motivation and critical thinking skills of students on Atomic Structure material. The study consists of several stages, namely analysis, design, development, implementation, and evaluation. The product developed was test to 35 students of grade X MIA 4 at SMAN 3 Bone of Academic Year 2019/2020. The validity of the product was test by two assessors. This study employed the stages of TGT model, namely class presentation, group work, games, tournament, and appreciation. The stages of chemistry quiz was started from association activity and presented in a form of a quiz or question which used HOTS questions along with the games to motivate the students in learning and think critically. The results of the study reveal that: (1) the mean score of product validity is 3.71 (very valid); (2) the data of learning motivation questionnaire $\mathrm{X}^{-}=3.31$ (high); (3) the mean score of $\mathrm{N}$ Gain of KBK is 0.79 (high); (4) The teacher and students indicated a very positive response with the percentage of $96.88 \%$ and $87.11 \%$. Therefore, the conclusion is the chemistry quiz technique based on HOTS in TGT Model developed in chemistry learning on Atomic Structure material is valid, practical, and effective to enhance learning motivation and critical thinking skills of students.

Keywords: Chemistry Quiz Technique; HOTS; TGT; Learning Motivation; Critical Thinking Skills.

\section{PENDAHULUAN}

Kurikulum memiliki pengaruh yang besar terhadap pengembangan potensi peserta didik. Perubahan dan pengembangan kurikulum kerap dilakukan dengan menyesuaikan tuntutan zaman yang selalu berubah demi mewujudkan peserta didik yang berkualitas. Mewujudkan peserta didik yang berkualitas tidak cukup hanya melalui pengembangan kurikulum. Dukungan dan kerja sama yang baik antar semua pihak yang terkait dalam melaksanakan pengembangan kurikulum dibutuhkan untuk menciptakan lingkungan belajar yang efektif bagi peserta didik. Lingkungan belajar yang efektif membantu meningkatkan kualitas peserta didik dalam pembelajaran.

Pembelajaran pada era revolusi industri 4.0 menuntut peserta didik memiliki kompetensi dan keterampilan abad ke-21 yaitu kreatif, kritis, komunikatif dan kolaborasi yang dapat terwujud melalui implementasi kurikulum 2013 (Mujib \& Rasyid, 2019). Implementasi kurikulum 2013 memberikan penguatan pola pembelajaran yang berpusat pada peserta didik. Peserta didik dapat belajar pada siapa saja dan di mana saja, termasuk memilih materi yang akan dipelajarinya. Selain itu, perkembangan transformasi informasi dan tekhnologi yang sangat pesat, memberikan kemudahan dan kemandirian peserta didik dalam belajar dan mengakses ilmu pengetahuan sehingga peserta didik akan memperoleh banyak informasi yang dapat mempengaruhi kehidupannya dimasa yang akan datang. Namun, dapat berdampak negatif jika dalam proses pengolahan informasi (belajar) tersebut tidak diorganisir dengan baik. Untuk itu, diperlukan pengorganisasian belajar yang baik.

Pengorganisasian belajar yang baik memerlukan upaya dan keterampilan dari guru sebagai pendamping belajar peserta didik. Hal ini dapat ditempuh oleh guru dengan menerapkan berbagai cara seperti penggunaan metode, strategi, media, teknik dan taktik pembelajaran yang dapat dikemas dalam model pembelajaran. Adapun, model pembelajaran yang digunakan oleh guru harus sesuai dengan tujuan pembelajaran yang akan dicapai sehingga diperoleh hasil yang lebih optimal.

Hasil optimal yang diharapkan tersebut tidak selalu tercapai. Berdasarkan hasil diskusi dengan teman sejawat, 
diperoleh gambaran bahwa salah satu permasalahan yang dihadapi oleh guru di dalam kelas adalah rendahnya motivasi belajar dan keterampilan berpikir kritis peserta didik dalam mempelajari materi pelajaran. Peserta didik masih cenderung menggunakan metode menghafal dalam belajar. Pada pembelajaran kimia misalnya, bila peserta didik selalu membiasakan diri menggunakan metode menghafal dalam belajar, maka materi itu tidak akan tersimpan lama dalam memori atau ingatan. Di sisi lain, mempelajari kimia tidak cukup hanya dengan mengingat dan menghafal teori atau rumus saja, tetapi konsep teorinya perlu dipahami dan dikaitkan, serta diterapkan dalam kehidupan sehari-hari.

Hasil observasi yang dilakukan di

SMA Negeri 3 Bone menunjukkan bahwa pada umumnya peserta didik kurang terampil menganalisis masalah yang berkaitan dengan penerapan konsep kimia dalam kehidupan sehari-hari. Pertanyaan atau soal yang diajukan dalam pembelajaran sering kali hanya berada pada tingkat kognitif mengingat, memahami dan menerapkan. Peserta didik kurang terlatih dalam mengerjakan soal-soal yang menuntut keterampilan berpikir tingkat tinggi seperti menganalisis, mengevaluasi dan mengkreasi pengetahuan yang dimilikinya. Di samping itu, metode yang diterapkan guru tidak relevan dengan materi yang diajarkan dan kurang melibatkan peserta didik secara aktif dalam proses pembelajaran. Teknik yang digunakan cenderung monoton yang berdampak pada rendahnya motivasi belajar peserta didik.

Sejalan dengan hal itu, diperlukan langkah untuk membangkitkan motivasi belajar peserta didik. Permainan dalam proses pembelajaran dapat membantu meningkatkan motivasi belajar peserta didik. Melalui permainan, peserta didik dapat mempelajari banyak hal tanpa harus merasa terbebani. Belajar sambil bermain sangat menarik dan menyenangkan, mendorong peserta didik untuk terlibat lebih aktif dalam pembelajaran. Salah satu model pembelajaran yang membuat peserta didik belajar sambil bermain adalah Model Team Games Tournament (TGT). Pembelajaran dengan Model TGT dapat mendorong peserta didik lebih aktif dalam pembelajaran dan meningkatkan motivasi belajar peserta didik (Wahyuningtyas \& Saputra, 2019). Aktivitas belajar dengan permainan yang dirancang dalam TGT memungkinkan peserta didik dapat belajar lebih rileks di samping menumbuhkan tanggung jawab, kejujuran, kerja sama, persaingan sehat dan keterlibatan belajar (Harahap, 2018:2).

Permainan dan turnamen dapat dirancang oleh guru menggunakan teknik cerdas cermat. Teknik cerdas cermat memiliki kesesuaian dengan Model TGT. Permainan cerdas cermat ini biasanya dilakukan dari mulai pertanyaan yang diajukan secara bergiliran sampai akhirnya saling berebut untuk menjawab pertanyaan (Fauzan et. al., 2017). Pelaksanaan teknik cerdas cermat pada umumnya dilakukan pada event atau pertandingan antar kelas maupun antar sekolah pada waktu tertentu dan hanya melibatkan sebagian kecil peserta didik yang dianggap berprestasi secara akademik di kelas atau di sekolah, peserta didik yang lain dalam kelas tidak dilibatkan. Cerdas cermat yang dilakukan pun cenderung di luar kelas, bukan seperti proses pembelajaran pada umumnya di dalam kelas.

Data yang diperoleh di SMA Negeri 3 Bone menunjukkan bahwa teknik cerdas cermat kimia pernah dilakukan oleh guru kimia di kelas dalam pembelajaran makromolekul dan memberikan pengaruh yang positif terhadap motivasi belajar peserta didik. Namun, tidak berpengaruh terhadap peningkatan keterampilan berpikir kritis peserta didik. Cerdas cermat yang dilakukan bersifat monoton, membutuhkan waktu yang relatif lama untuk pencapaian indikator pembelajaran secara menyeluruh dan terbatas pada kegiatan tanya jawab saja serta soal-soal yang digunakan hanya berada pada dimensi mengingat kembali informasi yang dijelaskan oleh guru sehingga tidak meningkatkan keterampilan berpikir kritis peserta didik. Berpikir kritis merupakan 
proses dimana segala pengetahuan dan keterampilan dikerahkan dalam memecahkan permasalahan yang muncul, mengambil keputusan, menganalisis semua asumsi yang muncul dan melakukan investigasi atau penelitian berdasarkan data serta informasi yang telah didapat sehingga menghasilkan informasi atau simpulan yang diinginkan (Ariyana et al., 2018).

Untuk meningkatkan keterampilan berpikir kritis peserta didik, teknik yang digunakan harus disertai dengan soal-soal HOTS (High Order Thinking Skills) dalam pembelajaran. Tujuan utama dari HOTS adalah bagaimana meningkatkan kemampuan berpikir peserta didik pada level yang lebih tinggi, terutama yang berkaitan dengan kemampuan untuk berpikir secara kritis dalam menerima berbagai jenis informasi, berpikir kreatif dalam memecahkan suatu masalah menggunakan pengetahuan yang dimiliki dan membuat keputusan dalam situasi-situasi yang kompleks (Saputra, 2016).

SMA Negeri 3 Bone memiliki guru yang berpotensi melaksanakan pembelajaran berbasis HOTS. Hanya karena kurang diterapkan dan tidak dibiasakan dalam pembelajaran serta tidak dipadukan dengan teknik yang tepat sehingga peserta didik merasa kesulitan dan cenderung kurang terlatih dalam berpikir kritis. Pada umumnya, soal-soal HOTS hanya digunakan oleh guru sebagai tindak lanjut pada program pengayaan sehingga kurang memotivasi peserta didik yang lain. Data statistik menunjukkan bahwa tingkat pengaruh motivasi belajar peserta didik berada pada angka 95\% terhadap pencapaian tujuan pembelajaran (Silva et al., 2018).

Terkait hal itu, perlu dikembangkan teknik cerdas cermat kimia berbasis HOTS dalam Model TGT. Teknik ini diharapkan efektif diterapkan dalam kelas dan membantu peserta didik dalam pembelajaran kimia. Pada pembelajaran kimia, materi struktur atom memiliki banyak konsep yang berkaitan dengan kehidupan sehari-hari. Dengan mempelajari materi tersebut, peserta didik dapat mengkonstruk pengetahuan yang dimilikinya kemudian menghubungkannya dengan kehidupan sehari-hari sehingga tepat diajarkan dan diterapkan untuk memotivasi peserta didik. Selain itu, penggunaan soalsoal HOTS dalam pengembangan teknik cerdas cermat ini dikemas dalam bentuk kuis atau pertanyaan yang di dalamnya terdapat permainan (games) sehingga dapat melatih dan membantu membangun pengetahuan peserta didik melalui pola berpikir kritis untuk menemukan jawaban serta memecahkan masalah.

SMA Negeri 3 Bone sebagai tempat penelitian. Sekolah ini merupakan salah satu sekolah percontohan implementasi kurikulum 2013 yang pertama di Kabupaten Bone sehingga sangat mendukung untuk peningkatan dan pengembangan kualitas atau potensi peserta didik dalam pembelajaran kimia. Berdasarkan latar belakang di atas, kiranya perlu dilakukan penelitian tentang "Pengembangan Teknik Cerdas Cermat Kimia Berbasis HOTS dalam Model Team Games Tournament untuk Meningkatkan Motivasi Belajar dan Keterampilan Berpikir Kritis Peserta Didik pada Pembelajaran Kimia di SMA Negeri 3 Bone". Adapun tujuan penelitian ini adalah untuk mengetahui bagaimana gambaran dan seberapa besar kualitas teknik cerdas cermat kimia berbasis HOTS dalam Model TGT untuk meningkatkan motivasi belajar dan keterampilan berpikir kritis peserta didik pada pembelajaran struktur atom.

\section{METODE}

Jenis penelitian $\mathrm{R} \& \mathrm{D}$ ini mengacu pada model pengembangan ADDIE yang terdiri dari tahap analisis, perancangan, pengembangan, implementasi dan evaluasi. Pengembangan teknik cerdas cermat kimia berbasis HOTS pada materi struktur atom ini dilaksanakan di SMA Negeri 3 Bone dan diujicobakan pada 35 peserta didik kelas $\mathrm{X}$ MIA 4 semester ganjil tahun pelajaran 2019/2020. Instrumen penelitian yang digunakan meliputi RPP, LK, Lembar pengamatan keterlaksanaan teknik cerdas cermat kimia berbasis HOTS, angket motivasi belajar, lembar tes keterampilan 
berpikir kritis, angket respon guru dan peserta didik. Produk yang dikembangkan telah divalidasi oleh dua orang validator ahli. Teknik analisis data pada pengembangan teknik cerdas cermat kimia berbasis HOTS ini menggunakan teknik analisis statistik deskriptif. Data yang dianalisis adalah data tentang kualitas pengembangan teknik cerdas cermat kimia berbasis HOTS yang meliputi data kevalidan, kepraktisan dan keefektifan.

\section{HASIL DAN PEMBAHASAN}

\section{Proses Pengembangan Teknik Cerdas Cermat Kimia Berbasis HOTS}

Pengembangan teknik cerdas cermat kimia berbasis HOTS dalam penelitian ini merujuk pada tiga syarat kualitas yaitu valid, praktis dan efektif menurut Nurdin (2007). Proses pengembangan dimulai dari tahap analisis yaitu dengan menganalisis kompetensi, karakteristik peserta didik dan materi. Analisis kompetensi didasarkan pada data hasil Ujian Nasional dari Pusat Penilaian Pendidikan Balitbang Kemdikbud (2018) dan pengalaman selama mengampu mata pelajaran kimia di kelas X SMA Negeri 3 Bone. Dari hasil analisis kompetensi, diperoleh dua kompetensi dasar yang masih membutuhkan upaya dari guru dalam memaksimalkan pencapaian tujuan pembelajaran, khususnya dalam meningkatkan motivasi belajar dan keterampilan berpikir kritis peserta didik. Kompetensi dasar yang dimaksud adalah KD 3.3 dan 3.4, yaitu kompetensi menganalisis dan mengolah struktur atom, hubungan konfigurasi elektron serta diagram orbital.

Analisis karakteristik peserta didik dilakukan melalui kegiatan observasi di kelas pada saat proses pembelajaran berlangsung dan diperoleh hasil kapasitas belajar peserta didik yang meliputi motivasi belajar, rasa ingin tahu, percaya diri, dan kerja sama pada proses pembelajaran sebelum menggunakan teknik cerdas cermat kimia menunjukkan hasil kurang maksimal. Karakteristik pengetahuan peserta didik hanya terbatas pada kemampuan mengingat
(C1), memahami (C2), dan menerapkan (C3). Karakteristik keterampilan peserta didik yang meliputi kemampuan dalam mempresentasekan hasil diskusi atau memberikan gagasan/ ide dan keterampilan berpikir kritis, juga masih tergolong rendah. Selanjutnya, dilakukan analisis materi. Materi struktur atom berada pada level 3 (penalaran) dengan dimensi proses berpikir menganalisis (C4) (Mujib \& Rasyid, 2019). Analisis sub materi yang dimaksud adalah partikel dasar penyusun atom (proton, elektron dan neutron), bilangan kuantum, konfigurasi elektron dan diagram orbital, serta letak unsur dalam sistem periodik.

Setelah tahap analisis, dilakukan tahap perancangan yang dilakukan dengan menganalisis sasaran pengembangan produk, tujuan pengembangan produk, penyusunan teknik pembelajaran dan instrumen penilaian. Dalam tahap perancangan ini, tujuan pembelajaran dalam RPP dirumuskan dengan menggunakan kata kerja operasioanal (KKO) dari C4 - C6 (menganalisis, mengevaluasi dan mencipta). KKO yang dimaksud seperti: merincikan, menganalisis, membandingkan, membedakan, mendeteksi, merancang, menyajikan, mengidentifikasi dan mempresentasekan. Adapun rancangan gambaran teknik cerdas cermat kimia berbasis HOTS dalam Model TGT yang disusun dalam RPP meliputi kegiatan pendahuluan yaitu pembagian kelompok (tim) secara heterogen, terdiri dari 6 kelompok beranggotakan masing-masing 5 atau 6 peserta didik; kegiatan inti terdiri dari penyajian kelas dengan menggunakan pendekatan saintifik dan memulai tahapan cerdas cermat pada kegiatan mengasosiasi dalam bentuk diskusi kelompok serta pengerjaan soal-soal secara cepat dan tepat pada LK, dan kegiatan penutup. Semua produk dan instrumen yang sudah dirancang dilanjutkan ke tahap pengembangan.

Tahap pengembangan dilakukan dengan menguji kevalidan produk oleh dua orang validator ahli dari Jurusan Kimia FMIPA UNM. Selanjutnya, dilakukan tahap implementasi. Pada tahap implementasi, uji 
coba produk dilakukan pada 35 orang peserta didik kelas X MIA 4 SMA Negeri 3 Bone semester ganjil tahun pelajaran 2019/2020 dan dilaksanakan sebanyak 6 kali pertemuan, yaitu 4 kali tatap muka pembelajaran (teknik cerdas cermat kimia berbasis HOTS) dan 2 kali pertemuan untuk tes keterampilan berpikir kritis (pretest dan posttest) serta pengisian angket (angket respon peserta didik dan angket motivasi belajar). Dalam uji coba ini, proses pembelajaran dipandu oleh peneliti sendiri dan dibantu oleh dua orang guru kimia yang sudah memiliki pengalaman dalam kegiatan pembelajaran. Dua orang guru kimia ini bertindak sebagai pengamat (observer) pada setiap pertemuan dalam proses pembelajaran. Tahap terakhir, yaitu tahap evaluasi yang bertujuan untuk mengumpulkan data pada setiap tahapan yang digunakan untuk penyempurnaan produk dan sebagai tahapan untuk mengetahui seberapa besar kepraktisan dan keefektifan produk yang dikembangkan dalam proses pembelajaran.

\section{Kualitas Hasil Pengembangan Teknik Cerdas Cermat Kimia Berbasis HOTS}

a. Analisis Data Kevalidan

Analisis data kevalidan diperoleh dari hasil pemeriksaan oleh dua orang ahli (validator) terhadap RPP, lembar kerja (LK) materi struktur atom, dan lembar tes keterampilan berpikir kritis (KBK) serta instrumen pendukung lainnya seperti lembar pengamatan keterlaksanaan teknik cerdas cermat kimia, angket motivasi belajar, angket respon peserta didik dan angket respon guru. Hasil analisis data kevalidan dapat dilihat pada Tabel 1.

Tabel 1. Rangkuman Hasil Analisis Data Kevalidan

\begin{tabular}{llcl}
\hline No. & \multicolumn{1}{c}{ Data Kevalidan } & $\begin{array}{c}\text { Rata-rata } \\
\text { Nilai } \\
\text { Total }\end{array}$ & Kategori \\
\hline 1. & Rencana Pelaksanaan Pembelajaran (RPP) & 3,62 & $\begin{array}{l}\text { Sangat Valid } \\
\text { 2. }\end{array}$ \\
2. Lembar Kerja (LK) & 3,63 & $\begin{array}{c}\text { Sangat Valid } \\
\text { 3. }\end{array}$ & Lembar Tes Keterampilan Berpikir Kritis (KBK) \\
4. Lembar Keterlaksanaan Teknik Cerdas Cermat & 3,75 & 3,58 & Sangat Valid \\
& Kimia Berbasis HOTS & 3,64 & Sangat Valid \\
5. Angket Motivasi Belajar & 3,83 & Sangat Valid \\
6. & Angket Respon Peserta Didik & 3,94 & Sangat Valid \\
7. Angket Respon Guru & 3,71 & Sangat Valid \\
\hline
\end{tabular}

Penilaian secara umum oleh para ahli terhadap instrumen yang dirancang memenuhi data kevalidan dan dapat digunakan dalam pembelajaran (penelitian). b. Analisis Data Kepraktisan

Data kepraktisan teknik cerdas cermat kimia berbasis HOTS diperoleh melalui data pada lembar pengamatan keterlaksanaan teknik cerdas cermat kimia berbasis HOTS dan angket respon guru oleh dua orang guru kimia yang telah memiliki pengalaman dalam kegiatan pembelajaran. Adapun angket respon guru terdiri dari indikator motivasi, suasana kelas dan keterampilan proses. Hasil analisis data kepraktisan dapat dilihat pada Tabel 2.

Tabel 2. Rangkuman Hasil Analisis Data Kepraktisan

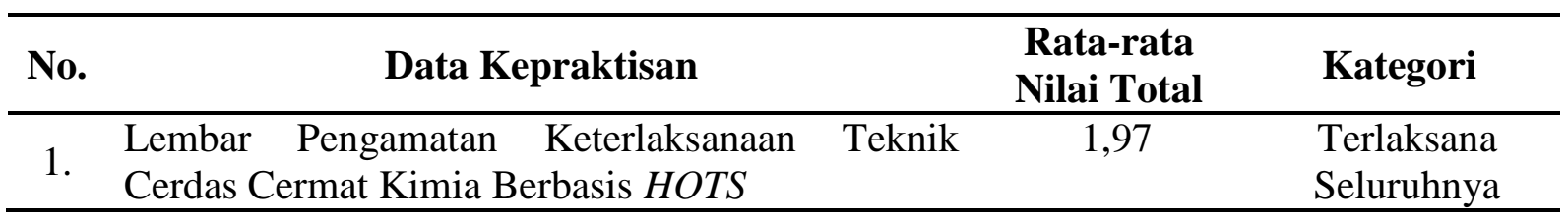


Data analisis pada tabel 2, menunjukkan bahwa teknik cerdas cermat kimia berbasis HOTS memenuhi kriteria kepraktisan.

c. Analisis Data Keefektifan

Analisis data keefektifan teknik cerdas cermat kimia berbasis HOTS diperoleh melalui data angket motivasi belajar peserta didik, data angket respon peserta didik dan data lembar tes keterampilan berpikir kritis. Angket motivasi belajar meliputi indikator semangat dalam pembelajaran, memiliki rasa keingintahuan, mampu mengerjakan tugas, memiliki rasa percaya diri, memiliki daya konsentrasi tinggi dan kerja sama. Angket respon peserta didik meliputi respon terhadap kegiatan pembelajaran dan respon terhadap soal-soal HOTS. Pada angket respon peserta didik terdiri dari beberapa indikator, yaitu minat dan perhatian mengikuti pembelajaran, kerja sama, rasa percaya diri, tanggung jawab, pemahaman konsep, keterampilan proses kognitif, isi dan ketertarikan. Analisis data lembar tes keterampilan berpikir kritis meliputi data pretest dan postest. Adapun indikator keterampilan berpikir kritis yaitu memberikan penjelasan sederhana, membangun keterampilan dasar, memberikan penjelasan lebih lanjut, mengatur strategi dan taktik dan menyimpulkan. Hasil analisis data keefektifan teknik cerdas cermat kimia berbasis HOTS dalam Model TGT dapat dilihat pada Tabel 3.

Tabel 3. Rangkuman Hasil Analisis Data Keefektifan

\begin{tabular}{clcc}
\hline No. & \multicolumn{1}{c}{ Data Keefektifan } & $\begin{array}{c}\text { Nilai } \\
\text { Rata-rata }\end{array}$ & Kategori \\
\hline 1. & Angket Motivasi Belajar & 3,31 & Tinggi \\
2. & Angket Respon Peserta Didik & $87,11 \%$ & Sangat Positif \\
3. & Angket Keterampilan Berpikir Kritis & 0,79 & Tinggi \\
\hline
\end{tabular}

Data analisis pada tabel 3, menunjukkan bahwa teknik cerdas cermat kimia berbasis HOTS memenuhi kriteria keefektifan.
Hasil rata-rata analisis angket motivasi belajar dan persentase tiap indikator keterampilan berpikir kritis dapat dilihat pada Gambar 1 dan Gambar 2.

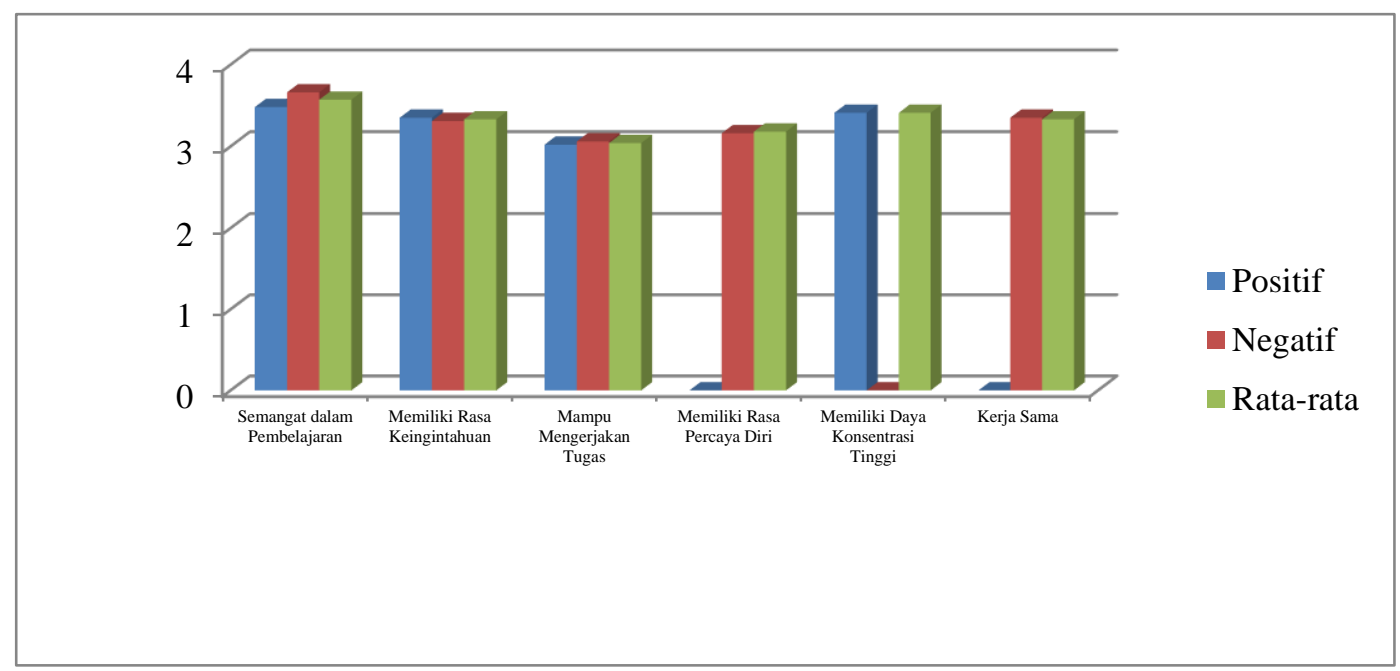

Gambar 1. Grafik Analisis Angket Motivasi Belajar 


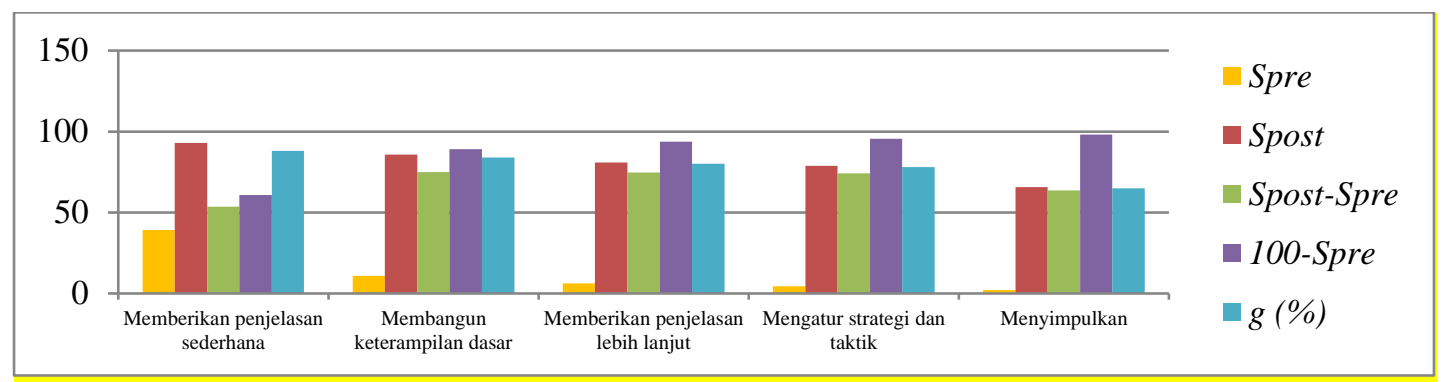

Gambar 2. Grafik Persentase Tiap Indikator Keterampilan Berpikir Kritis

\section{Profil Produk Teknik Cerdas Cermat Kimia Berbasis HOTS}

Produk teknik cerdas cermat kimia berbasis HOTS ini dikembangkan pada 14 tujuan pembelajaran yang akan dicapai pada materi struktur atom (sub materi partikel dasar penyusun atom, bilangan kuantum, konfigurasi elektron dan diagram orbital serta letak unsur dalam sistem periodik unsur), terbagi ke dalam 8 tujuan pembelajaran kognitif (pengetahuan) dan 6 tujuan pembelajaran psikomotorik (keterampilan). Selanjutnya, 14 tujuan pembelajaran ini diintegrasikan ke dalam empat RPP. Komponen RPP yang disusun terdiri atas kegiatan pendahuluan, kegiatan inti dan kegiatan penutup. Setiap RPP disusun dengan alokasi waktu $3 \times 45$ menit dan telah dilengkapi dengan instrumen penilaian (afektif, kognitif dan keterampilan) berupa soal-soal HOTS yang dikemas dalam Lembar Kerja (LK), soal rebutan, soal turnamen, soal tes akhir pertemuan dan tes KBK. Produk teknik cerdas cermat kimia berbasis HOTS yang dikembangkan menggunakan Model TGT.

Selain Model TGT, produk teknik cerdas cermat kimia berbasis HOTS yang dikembangkan juga menggunakan pendekatan saintifik 5M. Tahapan cerdas cermat kimia dimulai pada kegiatan mengasosiasi. Pada kegiatan ini, peserta didik akan mengerjakan soal-soal HOTS yang ada pada lembar kerja A, B, C sesuai dengan petunjuk soal dan alokasi waktu yang telah ditentukan. yaitu tahap pertama untuk Lembar Kerja A berupa pengambilan nomor soal secara acak oleh perwakilan setiap kelompok, bentuk soal HOTS berupa soal pernyataan benar/ salah, isian dan pilihan ganda. Tahap kedua untuk Lembar Kerja B berupa pengambilan kartu soal secara acak oleh pergantian perwakilan setiap kelompok, bentuk soal HOTS berupa soal uraian. Tahap ketiga untuk Lembar Kerja C, berupa soal melengkapi tabel dan disertai dengan permainan soal cepat tepat serta soal rebutan. Selanjutnya, tiga kelompok yang memiliki poin tertinggi mengikuti tahap turnamen dan diberi penghargaan (reward).

\section{SIMPULAN DAN SARAN}

Simpulan yang dapat dikemukakan berdasarkan hasil penelitian dan pengembangan yang telah dilakukan adalah teknik cerdas cermat kimia berbasis HOTS dalam Model TGT mengacu pada model pengembangan ADDIE dan menggunakan pendekatan saintifik, dimana tahapan cerdas cermat dimulai pada kegiatan mengasosiasi dan memiliki karakteristik/ ciri khas pada setiap tahap, yaitu tahap pertama untuk Lembar Kerja A (soal isian, pilihan ganda dan pernyataan benar/salah), tahap kedua untuk Lembar Kerja B (soal uraian) dan tahap ketiga untuk Lembar Kerja C (soal melengkapi tabel), dirangkaikan pula dengan permainan soal cepat tepat serta soal rebutan. Selanjutnya, tiga kelompok yang memiliki poin tertinggi mengikuti tahap turnamen dan diberi penghargaan (reward).

Kualitas teknik cerdas cermat kimia berbasis HOTS dalam model TGT memenuhi kriteria kevalidan, kepraktisan dan keefektifan. Rata-rata nilai kevalidan adalah 3,71 (sangat valid). Rata-rata nilai angket motivasi belajar adalah 3,31 (tinggi). Ratarata nilai $\mathrm{N}-$ Gain $\mathrm{KBK}$ adalah 0,79 (tinggi). Respon guru dan peserta didik sangat positif. 
Dengan demikian, produk yang dikembangkan layak digunakan dalam pembelajaran kimia.

\section{DAFTAR RUJUKAN}

Ariyana, Y., Pudjiastuti, A., Bestary, R., \& Zamroni. (2018). Buku Pegangan Pembelajaran Berorientasi pada Keterampilan Berpikir Tingkat Tinggi. Jakarta: Direktorat Jenderal Guru dan Tenaga Kependidikan Kementerian Pendidikan dan Kebudayaan.

Fauzan, M. N., Resdiana, W., \& Hamidin, D. (2017). Aplikasi Cerdas Cermat Online Real Time untuk Sekolah Dasar. Jurnal Informatika, 14(1), 2227.

Harahap, D. F. (2018). Penerapan Strategi Pembelajaran TGT Dibandingkan dengan TSTS dalam Meningkatkan Hasil Belajar Kimia Siswa. Science \& Technology (ST), 1(3), 1-6.

Mujib, \& Rasyid, M. F. (2019). Modul Penyusunan Soal Keterampilan Berpikir Tingkat Tinggi (Higher Order Thinking Skills) Kimia. Jakarta: Direktorat Pembinaan Sekolah Menengah Atas Direktorat Jenderal Pendidikan Dasar dan Menengah Kementerian Pendidikan dan Kebudayaan.

Nurdin. (2007). Model Pembelajaran Matematika yang Menumbuhkan Kemampuan Metakognitif untuk Menguasai Bahan Ajar. Surabaya: UNESA.

Pusat Penilaian Pendidikan Balitbang Kemdikbud. (2018). Nilai Ujian Nasional. Jakarta: Puspendik Balitbang Kemdikbud.

Saputra, H. (2016). Pengembangan Mutu Pendidikan Menuju Era Global: Penguatan Mutu Pembelajaran dengan Penerapan HOTS (High Order Thinking Skills). Bandung: SMILE's Publishing.

Silva, W. F., Fonseca Mendoza, A. L., \& Chiquillo-Rodelo, J. (2018). Statistical Significance Between
Student Motivation, Traditional Teaching and Problem-Based Learning Strategy. Contemporary Engineering Sciences, 11(84), 41794186.

Wahyuningtyas, S., \& Saputra, W. (2019). Modifikasi Model Pembelajaran Kooperatif Tipe Teams Games Tournament dan Strategi Pembelajaran Tugas dan Paksa. Prosiding Seminar Nasional Pendidikan KALUNI, LPPM Universitas Indraprasta PGRI Jakarta, 2. 